\title{
WINTER COVER CROPS SOWING SYSTEMS FOR PLANTING LETTUCE
}

Lidiane Fernandes Colombari, Vitor Massami Imaizumi, Luiz Felipe Guedes Baldini, Prínscilla Pâmela Nunes Chaves, Rumy Goto

${ }^{1}$ Universidade Estadual Paulista "Júlio de Mesquita Filho", Faculdade de Ciências Agronômicas de Botucatu, BotucatuSP, Fazenda Lageado, Rua José Barbosa de Barros, 1780 - CEP 18610-307, Botucatu/SP. Email:

colombarifl@yahoo.com.br

\section{SUMMARY}

The sowing system, as well as the species used as cover crops, may interfere with the production of straw and the development of further crops. The objective of this research was to evaluate sowing systems for black oat (Avena strigosa Schreb) and white lupine (Lupinus albus) as cover crops, the dry matter production of these plants and their influence on Americana and Curly lettuces yield. Two experiments were performed, one for each lettuce cultivar. The experimental design was composed of 8 treatments (factorial $4 \times 2$ ), evaluated in randomized blocks, with five replications. The first factor is related to four soil coverages (black oat, white lupine, black oat + white lupine and weed) and the second one is the sowing system (hand and mechanized in line). The cover plants drying was performed 47 days after planting and the amount of dry matter produced in the area (straw) was then measured. After 30 days from drying, varieties of Curly and Americana lettuce were planted under straw. The lettuce cultivars were evaluated for fresh mass, shoot height and head diameter. For both lettuces, the benefit of green manure was higher using black oat only or combined with white lupine, either hand or mechanized sowed.

Keywords: biomass; green manure; production; soil protection.

\section{SISTEMAS DE SEMEADURA DE PLANTAS DE COBERTURA DE INVERNO PARA PLANTIO DE ALFACE}

\section{RESUMO}

O sistema de semeadura, bem como a espécie utilizada como cobertura do solo, pode interferir na produção de palhada e no desenvolvimento das culturas subsequentes. Desse modo, o trabalho teve como objetivo avaliar sistemas de semeadura para as espécies de aveia preta (Avena strigosa Schreb) e tremoço branco (Lupinus albus) como plantas de cobertura, a produção de matéria seca dessas coberturas e sua influência na produtividade de alface americana e crespa. Foram conduzidos dois experimentos, um para cada cultivar de alface. 0 delineamento experimental foi composto de 8 tratamentos, resultantes de um fatorial $4 \times 2$, avaliados em blocos ao acaso, com cinco repetições. O primeiro fator corresponde a quatro coberturas de solo (aveia preta, tremoço branco, aveia preta + tremoço branco e vegetação espontânea) e o segundo, a duas formas de semeadura (manual a lanço e mecanizada em linha). A dessecação das plantas de cobertura foi realizada 47 dias após seu plantio, mensurando-se a quantidade de matéria seca (palhada) produzida na área. Decorridos 30 dias a partir da dessecação, variedades de alface crespa e americana foram cultivadas sob a palhada. As cultivares de alface foram avaliadas quanto à massa fresca, altura da parte aérea e diâmetro da "cabeça". Para a alface crespa e americana ficou evidente o benefício da adubação verde com a utilização da aveia preta cultivada de forma isolada ou consorciada com o tremoço branco, quer manejada em plantio manual ou mecanizada.

Palavras chave: adubação verde; biomassa; proteção do solo.

\section{INTRODUCTION}

Cover plants are used in the cultivation of several vegetables, single or intercropped (KIELING et al., 2009). Their residues can be kept on the soil surface in the no-tillage system, where the soil mobilization is restricted to the planting line or incorporated into the soil in the conventional planting system (WUTKE et al., 2007a). 
Plants used as soil covers are important to reduce the transportation of particles by wind and rain (FERREIRA et al., 2009), preventing soil erosion. They play an important role in the conservation of moisture providing a smaller variation in soil temperature (CARNEIRO et al., 2013), and maintaining or increasing its organic matter content, supporting biological activity. These covers crops along with the mineralization process, recycle and provide nutrients which can increase plants yield (SOLINO et al., 2010).

These cover crops can be grown with economic crops in rotative schedule (in different periods of area occupation) or at the same time, in interleaved lines, through mechanized sowing systems or hand.

During the sowing stage seeds can be distributed by hand or mechanically. Despite having irregular sowing and uneven emergence, the advantage of hand sowing is the speed. In the mechanized sowing system, seeds are distributed using of limestone distributing machines, being later incorporated to the soil using harrow or land roller or using seeders, resulting in greater uniformity and percentage of germination (BARBOSA; SANTIAGO, 2013).

For the use of plants as cover crops some parameters such as climate, soil and the carbon / nitrogen ratio $(\mathrm{C} / \mathrm{N})$ of straw must be considered, as they have influence in the production of dry matter and waste decomposition rate (REDIN et al., 2016).

Grasses provide larger amount of dry matter due to their high $\mathrm{C} / \mathrm{N}$ ratio, and remain in the soil for a longer period, despite the higher tendency of nutrients immobilization, particularly nitrogen (TEIXEIRA et al., 2009). On the other hand, legumes have low $\mathrm{C} / \mathrm{N}$ ratio, fast decomposition, and provide significant nitrogen content to further cultures (FERREIRA et al., 2014).

Thus, the amount of dry matter in the soil becomes important for both soil protection and availability of nutrients.

Among the species used as cover crops in winter, black oat (Avena strigosa Schreb) stands out by its dry matter yield, which can range from $1,532 \mathrm{~kg} \mathrm{ha}^{-1}$ (CARVALHO et al., 2013) to $6,000 \mathrm{~kg}$ ha $^{-1}$ (WUTKE et al., 2014), by its seeds, easily acquired and sown in the field, and by its fast growing rate (SILVA et al., 2006).

The white lupine (Lupinus albus) is another plant with great potential for cover crop. It is an annual species better known for its use in the field as a natural subsoiler, presenting a great nutrient cycling (CREMONEZ et al., 2013).

According to Oliveira et al. (2002), considering the characteristics of each region, species that have the potential to be used as cover crops, which means plants that produce an amount of dry matter enough to maintain or raise the fertility of soil and therefore increase the commercial crops yield, are not enough studied. Thus, the objective of this work was to evaluate sowing systems for the species of black oat (Avena strigosa Schreb) and white lupine (Lupinus albus) as cover crops, the dry matter production of these covers and its influence on lettuces americana and curly yield.

\section{MATERIALS AND METHODS}

The experiment was conducted on a farm in the municipality of Pardinho-SP (23-04'52" S; 4822'25"; 895 m altitude), from July 4, 2013 to November 20, 2013.

The soil of the region is sandy and was chemically analyzed at the beginning of the experiment: $\mathrm{pH}\left(\mathrm{CaCl}_{2}\right)$ : 5.7; M.O: $36 \mathrm{~g} \mathrm{dm}^{3}$; $\mathrm{P}$ ressyne: $223 \mathrm{mg} \mathrm{dm}^{-3} ; \mathrm{H}+\mathrm{Al}: 27 \mathrm{mmol}_{\mathrm{c}} \mathrm{dm}^{-3} ; \mathrm{K}$ : $6.3 \mathrm{mmol}_{\mathrm{c}} \mathrm{dm}^{-3}$; Ca: $66 \mathrm{mmol}_{\mathrm{c}} \mathrm{dm}^{-3}$; $\mathrm{Mg}: 13 \mathrm{mmol}_{\mathrm{c}}$ $\mathrm{dm}^{-3}$; SB: $85 \mathrm{mmol}_{\mathrm{c}} \mathrm{dm}^{-3}$; CTC: $112 \mathrm{mmol}_{\mathrm{c}} \mathrm{dm}^{-3}$ and $\mathrm{V}: 76 \%$

Two commercial lettuce cultivars were used in "Vanda" (curly) and "Maumy" (americana), evaluated in two independent experiments. In each trial we evaluated eight treatments in a factorial $4 \times 2+$ control (coverless soil) designed in randomized blocks, with five replications (Table 1 ).

Table 1. Description of treatments in a factorial scheme (4×2) for two cultivars of lettuce, curly (Vanda) and Americana (Maumy). Pardinho-SP, FCA / UNESP, 2013.

\begin{tabular}{ccc}
\hline First factor: four kinds of coverage & Second factor: two sowing systems \\
\hline Black oat & Hand & Mechanized in line \\
White lupine & & \\
Control (coverless soil) & & \\
\hline
\end{tabular}


The experiment was conducted in two stages. The first consisted of the cultivation of winter cover crops. The soil was prepared with plowing and harrowing, and with a rotary tiller, seven beds with an approximate height of $0.20 \mathrm{~m}$ were built. The cover crops were planted from two types of sowing: hand and mechanical (using a mechanical seeder of four lines, $0.25 \mathrm{~m}$ between lines). The amount used, recommended by Piraí Seeds (green manure seeds producer) is $80 \mathrm{~kg} \mathrm{ha}^{-1}$ of black oat seeds; $80 \mathrm{~kg} \mathrm{ha}^{-1}$ of white lupine seeds and mixing $40 \mathrm{~kg} \mathrm{ha}^{-1}$ of each species.

The cover crops drying was performed in September (47 days after sowing), using the herbicide glyphosate $\left(2 \mid \mathrm{ha}^{-1}\right)$, according to Casão Junior and Siqueira (2006). Soon after, the shoot of four samples of cover crops was collected using a frame of $0.25 \mathrm{~m}^{2}$ to evaluate the dry matter production. For dry matter evaluation, samples were weighed (fresh weight), wrapped in paper bags and placed in a kiln with air circulation at $65{ }^{\circ} \mathrm{C}$. After reaching constant weight, samples were weighed, and the total dry matter content was calculated and expressed in $\mathrm{t}$ $\mathrm{ha}^{-1}$.

The lettuce was planted under the cover plants layer. The experimental plots were composed by four rows with six lettuce plants $(0.25 \times 0.25 \mathrm{~m})$.

Lettuce seeds were sown in expanded polystyrene trays with 288 cells containing substrate from Carolina Soil company. Lettuce seedlings were transplanted to the experimental area after 30 days of cover crops drying, in the stage of four to five true leaves. Before transplant, the cover crop was cut into a layer using a roller-crimper device.

During the development of the lettuce, fertilization and weeding management was not performed. In the absence of rain, irrigation was performed using the sprinkler system.

The harvest of lettuce was accomplished 30 days after transplanting. Twelve plants of each experimental plot were evaluated.

Parameters such as shoot height $(\mathrm{cm})$ and fresh weight $(\mathrm{g})$ were evaluated for americana and curly lettuce and longitudinal and transverse diameter of the head $(\mathrm{cm})$ were evaluated for americana lettuce.

The statistical analysis of results was performed using analysis of variance (ANOVA). The means were compared by the Tukey test (5\% probability) using the software Sisvar 5.3 Programa de Análises Estatísticas e Planejamento de Experimentos da Universidade de Lavras (FERREIRA, 2010).

\section{RESULTS AND DISCUSSION}

For dry matter production in the hand sowing system, the use of black oat provided higher yields when sown alone and combined with white lupine. For the mechanized system, the dry matter production did not vary comparing all cover plants, and in general the amount produced was similar to the hand system. Despite its greater accuracy, the mechanized system has high costs for implementation, thus, small producers can economically benefit with the hand sowing system, especially when using black oat, either alone or combined.

Table 2. Dry matter production of cover crops sowed by hand and mechanized. Pardinho-SP, FCA/UNESP, 2013.

\begin{tabular}{lc}
\hline & \multicolumn{2}{c}{$\begin{array}{c}\text { Dry matter } \\
\text { Cover crops }\end{array}$} \\
\cline { 2 - 2 } & \multicolumn{1}{c}{ Sowing system } \\
\cline { 2 - 2 } Black oat & Hand \\
White lupine & $3.620 \mathrm{a}$ \\
Black oat + White lupine & $2.260 \mathrm{~b}$ \\
& $3.270 \mathrm{ab}$ \\
Black oat & Mechanized \\
White lupine & $3.190 \mathrm{a}$ \\
Black oat + White lupine & $2.370 \mathrm{a}$ \\
\hline CV (\%) & $3.140 \mathrm{a}$ \\
\hline *Means followed by the same letter in the column did not differ significantly from each other by Tukey's test, $\mathrm{p}<0.05$.
\end{tabular}


* CV $=$ Coefficient of variation.

${ }^{\mathrm{n}}$ Not significant by Tukey test at $5 \%$ probability.

Similar results of oat dry mass production were achieved by Souza et al. (2013), with an yield of 2,800 $\mathrm{kg} \mathrm{ha}^{-1}, 95$ days after sowing, whereas Oliveira et al. (2015) obtained an average of $3,400 \mathrm{~kg} \mathrm{ha}^{-1}$ during 5 years, however, the authors do not mention the phenological stage of the plants at the moment of drying it. Goulart et al. (2009), using the same cover crop of this research, obtained dry mass amount of 5,$260 ; 3,300$ and 2,630 $\mathrm{kg} \mathrm{ha}^{-1}$ for black oat, white lupine, and black oat + white lupine combined, respectively.

Regarding cover crops, it is important to consider the amount of dry mass produced, because the straw will protect the soil from erosion, as well as weed management, and maintain moisture and soil temperature. However, despite the excess of straw provides great weed management, it can compromise the lettuce development (HIRATA et al., 2014)

According to Silva et al. (2007), black oat is one of the most cultivated winter cover crops species, presenting high yield of dry matter; one of the reasons for its use (data confirmed in this and other researches mentioned above).

For shoot height, fresh mass and head diameter, there was a significant interaction between the cover crops and the sowing system of both Curly and Americana lettuce (Tables 2, 3 and 4).

The fresh lettuce mass did not differ between black oat and black oat + white lupine in both hand and mechanized sowing system (Table 3). However, the treatments produced higher fresh mass. For lettuce, fresh mass is a feature to determine yield, since they are classified according to their weight. In this research, considering the types of cover crops, the fresh mass ranged from $428.0 \mathrm{~g}$ to $576.0 \mathrm{~g}$, values within the classification standards of CEAGESP (2018) as "extra class" ( $\geq 400 \mathrm{~g}$ ).

Table 3. Fresh mass production and shoot height of curly lettuce plants grown after cover crops drying. Pardinho-SP, FCA/UNESP2013.

\begin{tabular}{|c|c|c|c|c|}
\hline \multirow[t]{3}{*}{ Cover crops } & \multicolumn{2}{|c|}{$\begin{array}{c}\text { Fresh Mass } \\
\text {----g---- }\end{array}$} & \multicolumn{2}{|c|}{$\begin{array}{c}\text { Shoot Height } \\
----\mathrm{cm}---\end{array}$} \\
\hline & \multicolumn{4}{|c|}{ Sowing system } \\
\hline & Hand & Mechanized & Hand & Mechanized \\
\hline Black oat & 576.0aA & 498.0bA & $32.94 a A$ & $32.06 \mathrm{aA}$ \\
\hline White lupine & $428.0 \mathrm{bB}$ & $466.0 \mathrm{aA}$ & $34.18 \mathrm{aA}$ & $31.60 \mathrm{bA}$ \\
\hline Black oat + White lupine & 573.0aA & $487.0 \mathrm{bA}$ & $30.17 b B$ & $33.40 \mathrm{aA}$ \\
\hline Control & $334.0 \mathrm{aC}$ & $334.0 \mathrm{aB}$ & $26.93 a C$ & $26.93 a \mathrm{~B}$ \\
\hline CV (\%) & \multicolumn{2}{|c|}{4.10} & \multicolumn{2}{|c|}{4.21} \\
\hline
\end{tabular}

For curly lettuce researches using different types of cover crops, Ziech et al. (2014), using black oat incorporated, cut and whole plant on the soil surface, obtained masses of 322.0, 183.0 and $189.0 \mathrm{~g}$, respectively. Silva et al. (2013) using Arachis pintoi as cover crop achieved yields of $276.0 \mathrm{~g}$ and $254.0 \mathrm{~g}$ using millet. For Mogor and Câmara (2007), the production for black oat was $174.35 \mathrm{~g}$ (cut) and $185.15 \mathrm{~g}$ (whole plant). All authors mentioned above achieved lower mass gains than the results of this research.
Pierre et al. (2010) evaluating the yield performance of lettuce cultivars Mimosa, Romana and Lisa, grown under organic farming using black oat straw, observed that these did not differ, however, they presented an average of 355 g. Oliveira et al. (2008), using Crotalaria juncea, Mucuna pruriens and Guandu Canjan, obtained higher means $(336.0 \mathrm{~g}, 315.8 \mathrm{~g}$ and $328.9 \mathrm{~g}$, respectively).

In more recent works with other species of cover crops, Paixão et al. (2016) studying curly lettuce (Elba cultivar) grown using Brachiaria 
grass as cover crop found values lower than that of this research, yielding $78.04 \mathrm{~g}$ for fresh mass and $21.54 \mathrm{~cm}$ for shoot height. This author observed a small reduction of the fresh mass $(74.34 \mathrm{~g})$ when the cultivation occurred using Mucuna aterrima, but with greater development of the plants $(24.5 \mathrm{~cm})$.

For curly lettuce shoot height, the different coverage treatments in the hand and mechanized sowing systems provided higher lettuce height, however, the highest heights were in the treatments with black oat and white lupine (both alone) in the hand sowing system. In the mechanized sowing the black oat also provided higher height, as well as black oat + white lupine, not differing between them (Table 3 ). The use of the cover crops allows better conditions for the development of the plant when compared to the control treatment.
There was no difference in the fresh mass of the Americana lettuce when cover crops in hand sowing are compared between them, except for the control treatment (Table 4). The larger fresh mass results $(775.0 \mathrm{~g})$ were achieved in the mechanized sowing using black oat as cover crop. On the other hand, Fontanetti et al. (2006) did not find differences in the fresh mass of Americana lettuce using Mucuna pruriens, Crotalaria juncea and Canavalia ensiformis as cover crops, obtaining values of 409.0, 332.0 and 294.0 g, respectively.

There was no difference between treatments for the shoot height of Americana lettuce, in both hand and mechanized systems. Only the Control group presented lower values (Table 4). These cover crops favored this features regardless the sowing system.

Table 4. Fresh mass production and shoot height of americana lettuce plants grown after cover crops drying. Pardinho-SP, FCA/UNESP, 2013.

$\begin{array}{lcc} & \text { Fresh Mass } & \text { Shoot Height } \\ \text { Cover crops } & --- \text {---- } & ---c m--\end{array}$

\begin{tabular}{lcccc} 
& \multicolumn{4}{c}{ Sowing system } \\
\cline { 2 - 5 } & Hand & Mechanized & Hand & Mechanized \\
\hline Black oat & $740.0 \mathrm{aAB}$ & $775.0 \mathrm{aA}$ & $12.73 \mathrm{aAB}$ & $12.46 \mathrm{aAB}$ \\
White lupine & $727.0 \mathrm{aB}$ & $687.0 \mathrm{bB}$ & $12.0 \mathrm{aBC}$ & $12.66 \mathrm{aA}$ \\
Black oat + White lupine & $778.0 \mathrm{aA}$ & $670.0 \mathrm{bB}$ & $13.0 \mathrm{aA}$ & $12.06 \mathrm{bAB}$ \\
Control & $387,0 \mathrm{aC}$ & $387.0 \mathrm{aC}$ & $11.70 \mathrm{aC}$ & $11.70 \mathrm{aB}$ \\
\hline CV (\%) & \multicolumn{3}{c}{4.51} \\
\hline
\end{tabular}

* Small letters in the column compare means of sowing system and capital letters in line compare means of types of cover crops by Tukey's test, $\mathrm{p}<0.05$.

$* \mathrm{CV}=$ Coefficient of variation

The height values of Americana lettuce plants are in accordance with those found in the literature. Hirata et al. (2014) growing Americana lettuce over Mucuna pruriensis straw obtained $219.8 \mathrm{~g}$ of fresh mass and height of $11.2 \mathrm{~cm}$ using Cajanus cajan straw. Mogor and Câmara (2007), achieved greater fresh masses (128.57 and 148.5 $\mathrm{g})$ and heights $(13.42$ and $13.9 \mathrm{~cm}$ ) of Americana lettuce using black oat.

The largest fresh mass of lettuce obtained using cover crops in this study may have been favored by nutrient recycling, which provides nutrients to lettuce continuously as there were no symptoms of nutritional deficiency.

Oats used as a cover plant provide $40 \%$ of the nitrogen of its dry matter content in the first four weeks (AITA and Giacomini, 2003).
Considering that lettuce is a short-cycle vegetable crop, approximately 30 days, depending on the environmental conditions of cultivation and the cultivar used, probably the nitrogen supplied by black oat in this research may have supplied the nutritional needs of the plant, which resulted in a better fresh mass and height when this cover is used alone or combined. This nutrient supports the vegetative growth, expands the photosynthetic area and increases the productive potential of the crop (FILGUEIRA, 2008).

The head diameter in Americana lettuce is an important parameter because it is a quality feature desired by the costumer. In Table 5, for longitudinal diameter in hand sowing system, black oat provided higher average $(13.46 \mathrm{~cm})$, differing from the white lupine $(12.13 \mathrm{~cm})$ and 
the Control $(11.83 \mathrm{~cm})$. Comparing the results of mechanized system, the white lupine presented higher average for longitudinal diameter differing from Control.

Andrade Júnior et al. (2005) studied the behavior of lettuce cultivars "Regina" and "Elisa" in different types of cover plants and found a larger longitudinal diameter of the "head" in soil covered with coffee husks.

Table 5. Diameter of americana lettuce plants grown after cover crops drying. Pardinho-SP, FCA/UNESP, 2013.

Longitudinal diameter

Cover crops
Transversal diameter $----c m---$

\begin{tabular}{lcccc}
\cline { 2 - 5 } & \multicolumn{4}{c}{ Sowing system } \\
\cline { 2 - 5 } & Manual & Mechanized & Manual & Mechanized \\
\hline Black oat & $13.46 \mathrm{aA}$ & $12.53 \mathrm{bAB}$ & $13.52 \mathrm{aA}$ & $12.33 \mathrm{aBC}$ \\
White lupine & $12.13 \mathrm{bB}$ & $13.06 \mathrm{aA}$ & $12.66 \mathrm{aA}$ & $14.06 \mathrm{bA}$ \\
Black oat + White lupine & $12.73 \mathrm{aAB}$ & $12.20 \mathrm{aAB}$ & $13.86 \mathrm{aA}$ & $11.80 \mathrm{bC}$ \\
Control & $11.83 \mathrm{aB}$ & $11.83 \mathrm{aB}$ & $13.53 \mathrm{aA}$ & $13.53 \mathrm{aAB}$ \\
\hline CV (\%) & \multicolumn{3}{c}{7.30}
\end{tabular}

* Small letters in the column compare means of sowing system and capital letters in line compare means of types of cover crops by Tukey's test, $\mathrm{p}<0.05$.

$* \mathrm{CV}=$ Coefficient of variation.

Regarding the transversal diameter, there was no difference between kinds of cover considering hand sowing. Considering the mechanized sowing system, the white lupine presented higher diameter compared with black oat and black oat + white lupine. However, the Control group did not differ from white lupine and black oat, both grown alone, what means that for a small producer or for economic matters, there is no need to buy cover crops seeds. The diameter of the "head" is an essential feature for harvesting, packing, and transporting.

On the study of green manure cover crops, Rodrigues et al. (2009) observed that when Saia Veia lettuce cultivars are grown on soil covered with plastic straw, the diameters of "head" are higher compared to the soil covered with sawdust and grass. Hirata et al. (2014) observed larger diameters in soils covered with Mucuna pruriensis.

The understanding of the phenomena involved in the head formation is complex, since they may involve responses in the plant metabolism related to fertility, phytotechnical practices, growing locations, genotypes, temperatures, photoperiods, moisture, light intensity and some other parameters that can act individually or combined (SOUZA et al., 2008). In Americana lettuce, the formation of the head occurs by the overlap of the new inner leaves in continuous process generating the massive head, in which deformed heads tends to result in lower diameters (BLIND; SILVA FILHO, 2015).

Features related to the size of the plants, such as diameter and height, provide important information, as the main kind of package for vegetables transportation is plastic or wooden boxes (SALA; COSTA, 2012). Thus, larger plants can be damaged in the packaging and transportation processes, reducing the commercial quality of the product (SUINAGA et al., 2013).

The diameter is a feature directly related to the fresh mass of the vegetable, very important for the producer, because it shows great yield. It is possible to infer that there was a variation in the head diameter of the Americana lettuce according to the cover crops and types of sowing studied in this work.

The diferences between this research and the literature for mass, height and diameter are due to the lettuce cultivar, the type of plant used as cover plant (grass or legume) and the environmental conditions to which the coverings were cultivated. This last parameter, associated with the carbon / nitrogen ratio of the residues, reflects the decomposition rate, that is, the cover crops with higher $\mathrm{C} / \mathrm{N}$ ratio (grasses) generates more stable and durable coverages, since their decomposition is slow (Brunetto et al., 2016). 
Plants with lower $\mathrm{C} / \mathrm{N}$ ratios (legume) have a high $\mathrm{N}$ content in the tissue, and decompose rapidly after their management, reducing the synchronism between the release and absorption of the nutrient by the following crop (FERREIRA et al., 2014).

The combination between grass and legume cover crops minimizes the problem of fast decomposition of residues, since the $\mathrm{C} / \mathrm{N}$ ratio of the residues is intermediate compared with the species cultivated alone (GIACOMINI et al., 2003), thus highlighting the results of this work, in which the combination of black oat and with white lupine provided economic gain for the lettuce crop. Although the mentioned authors have done their research in different environmental conditions, we can verify that the nutrient need between Curly and Americana lettuce is contrasting, which justifies the differences between treatments.

Sowing accuracy is of great importance for seed germination, emergence of seedlings, and development of plants. It is known that in the hand sowing system, the seeds that remain in upper layers are vulnerable to the attack of birds. This fact was observed during the conduction of the experiment, however, did not interfere in the dry mass yield of the plants used as green manure. On the other hand, in the mechanized system, despite the higher germination rate and seedling emergence uniformity, it was not observed in the present study a difference in sowing types for the development of cover crops, due to the regulation of the sowing depth.

\section{CONCLUSION}

The benefit of green manure was clear for Curly and Americana lettuces using black oat grown alone or combined with lupine, regardless the sowing system.

\section{REFERENCES}

AITA, C.; GIACOMINI, S.J. Crop residue decomposition and nitrogen release in single and mixed cover crops. Revista Brasileira de Ciência do Solo, v.27, n.4, p.601-612, 2003. http://dx.doi.org/10.1590/S0100$\underline{06832003000400004}$

ANDRADE JÚNIOR, V.C.; YURI, J.E.; NUNES, U.R.; PIMENTA, F.L.; MATOS, C.; FLORIO, F.C.A.; MADEIRA, D.M. Evaluation of mulch types on lettuce production. Horticultura Brasileira, v.23, n.4, p.899-903, 2005.
http://dx.doi.org/10.1590/S0102$\underline{05362005000400007}$

BARBOSA, F.R.; SANTIAGO, C.M. Technical information for irrigated rice cultivation in Mato Grosso do Sul: 2012- 2014. Embrapa Rice and Beans, 2013.

BLIND, A.D.; SILVA FILHO, D.F. Productivity performance in cultivars of crisphead lettuce in the dry season of central amazonia. Bioscience Journal, v.31, n.2, p.404-414, 2015.

BRUNETTO, G.; ROZANE, D.E.; MELO, G.W.B.; ZALAMENA, J.; GIROTTO, E.; LOURENZI, C.; COUTO, R.R.; TIECHER, T.; KAMINSKI, J. Management of soil fertility in temperate fruit orchards. In: Management and conservation of soil and water in small rural properties in southern Brazil: alternative management practices aiming at soil and water conservation. 2016. p.141-156

CARNEIRO, R.G.; MOURA, M.A.L.; SILVA, V.P.R.; SILVA JÚNIOR, R.S.; ANDRADE, A.M.D.; SANTOS, A.B. Study of soil temperature in two forest biomes in the periods, rainy and dry. Revista Brasileira de Geografia Física, v.6, n.4, p.10091022, 2013.

https://doi.org/10.26848/rbgf.v6i4.233092

CARVALHO, W.P.; CARVALHO, G.J.; ABBADE NETO, D.O.; TEIXEIRA, L.G.V. Agronomic performance of cover crops used as ground cover mulching in the fallow period. Pesquisa Agropecuária Brasileira, v.48. n.2, p.157-166, $2013 . \quad$ http://dx.doi.org/10.1590/S0100204X2013000200005

CASÃO JÚNIOR, R.; SIQUEIRA, R. Machines for management of vegetation and sowing in notillage. 2006. In: CASÃO JÚNIOR, R.; SIQUEIRA, R.; MEHTA, Y.R.; PASSINI, J.J. (Ed.). Quality no-tillage system. Londrina: IAPAR; Foz do Iguaçu: ITAIPU Binacional, 2006. p.85-126

CEAGESP. Standards and classification. Available in: $<$ http://

www.ceagesp.gov.br/produtos/alfaceamericana>. Access in: 23 ago. 2018.

CREMONEZ, P.A.; FEROLDI, M.; FERIDEN, A.; ROSSIL, E.; NADALETI, W.C.; ANTONELLI, J. 
Lupine: Management and Applications. Acta Iguazu, v.2, n.1, p.98-108, 2013.

FERREIRA, D.F. SISVAR - System of analysis of variance. Version 5.3. Lavras - MG: UFLA, 2010.

FERREIRA, P.A.A.; GIROTTO, E.; TRENTIN, G.; MIOTTO, A.; MELO, G.W. de; CERETTA, C.A.; KAMINSKI, J.; DEL FRARI, B.K.; MARCHEZAN, C.; SILVA, L.O.S.; FAVERSANI, J.C.; BRUNETTO, G. Biomass decomposition and nutrient release from black oat and hairy vetch residues deposited in a vi-neyard. Revista Brasileira de Ciência do Solo, v.38, n.5, p.1621-1632, 2014. http://dx.doi.org/10.1590/S0100-

$\underline{06832014000500027}$

FERREIRA, R.L.F.; ARAÚJO NETO, S.E.; SILVA, S.S.; ABUD, E.A.; REZENDE, M.I.F.L.; KUSDRA, J.F. Combination of cultivars, environments, tillage and mulching of soil influencing agronomical characteristics of lettuce. Horticultura Brasileira, v.27, n.3, p.383-388, 2009. http://dx.doi.org/10.1590/S0102$\underline{05362009000300023}$

FILGUEIRA, F.A.R. New manual of olericultura: Modern agro-technology in the production and commercialization of vegetables. 3. ed. Viçosa: Federal University of Viçosa, 2008.

FONTANÉTTI, A.; CARVALHO, G.J.; GOMES, L.A.A.; ALMEIDA, K.; MORAES, S.R.G.; TEIXEIRA, C.M. The use of green manure in crisphead lettuce and cabbage production. Horticultura Brasileira, v.24, n.2, p.146-150, 2006. http://dx.doi.org/10.1590/S010205362006000200004

GIACOMINI, S.J. Dry matter, $\mathrm{C} / \mathrm{N}$ ratio and nitrogen, phosphorus and potassium accumulation in mixed soil cover crops in Southern Brazil. Revista Brasileira de Ciência do Solo, v.27, n.2, p.325-334, 2003. http://dx.doi.org/10.1590/\$0100-

$\underline{06832003000200012}$

GOULART, P.; CAMPOS, S.; BASTIANI, M.; FONTANETTI, A.; MOREIRA, G.; PEREIRA, L. Biomass performance of winter cover crops in the suppression of spontaneous plants. Revista Brasileira de Agroecologia, v.4, n.2, p.139-143, 2009.
HIRATA, A.C.S.; HIRATA, E.K.; GUIMARÃES, E.C.; RÓS, A.B.; MONQUERO, P.A. No-tillage of crisphead lettuce on cover crops desiccated or mowed. Bragantia, v.73, n.2, p.178-183, 2014. http://dx.doi.org/10.1590/brag.2014.024

KIELING, A.S.; COMIN, J.J.; FAYAD, J.A.; LANA, M.A.; LOVATO, P.E. Winter cover crops in notillage system whitout herbicides: effects on weed biomass and tomato yield. Ciência Rural, v.39, n.7, p.2207-220, 2009. http://dx.doi.org/10.1590/S010384782009000700040

MOGOR, A.F.; CÂMARA, F.L.A. Organic lettuce production over black oat tillage, and different soil covering. Sciencias Agraria, v.8, n.3, p.239245, 2007.

OLIVEIRA, F.F; GUERRA, J.G.M.; ALMEIDA, D.L.; RIBEIRO, R.L.D.; ESPINDOLA, J.A.A.; RICCI, M.S.F; CEDDIA, M.B. Avaliação de coberturas mortas em cultura de alface sob manejo orgânico. Horticultura Brasileira, v.26, n.2, p.216-220, $2008 . \quad \quad$ http://dx.doi.org/10.1590/S0102$\underline{05362008000200017}$

OLIVEIRA, R.A.; SOUZA, M.; KURTZ, C.; LOVATO, P.E.; BRUNETTO, G.; COMIN, J.J. Dry matter production of winter cover crops and yie Id of onion over five years under no-tillage system agroecological . Cadernos de Agroecologia, v.10, n.3, 2015.

OLIVEIRA, T.K., CARVALHO, G.J., MORAES, R.N.S. Cover crops and their effects on bean plant in notillage system. Pesquisa Agropecuária Brasileira, v.37, n.8, p.1079-1087, 2002. http://dx.doi.org/10.1590/S0100$\underline{204 \times 2002000800005}$

PAIXÃO, C.M.; CAMILI, E. C.; GUIMARÃES, S. C.; SEABRA JUNIOR, S.; SILVA, A. R. B. Lettuce production in different crop soil in tropical conditions. Revista Agrariam, v.9, n.31, p.63 - 72, 2016.

PIERRI, L.; POLETTO, M.R.; SEEFELD, S.; MÓGOR, A. Performance of three lettuce cultivars conducted on no-tillage through organic system. Horticultura Brasileira, v.28, n.2, p.2766-2771, 2010. 
QUEIROZ, A.A. CRUVINEL, V.B.; FIGUEIREDO, K.M.E. Production of lettuce in function of fertilization organomineral. Enciclopédia Biosfera, v.14 n.25; p. 1053-1063, 2017. https://doi.org/10.18677/EnciBio 2017A84

REDIN, M.; GIACOMINI, S.J.; FERREIRA, P.A.A.; ECKHARDT, D.P. Soil cover and sustainable agriculture: species, dry matter and carbon and nitrogen cycling. In: Management and conservation of soil and water in small rural properties in southern Brazil: alternative management practices aiming at the conservation of soil and water. 2016. p 7-22.

RODRIGUES, D.S.; NOMURA, E.S.; GARCIA, V.A. Soil coverage affecting lettuce production in the organic system. Revista Ceres, v.56, n.3, p.32335, 2009.

SALA, F.C.; COSTA, C.P. Retrospective and trends of Brazilian lettuce crop. Horticultura Brasileira, v.30, n.2, p.187-194, 2012. http://dx.doi.org/10.1590/S0102$\underline{05362012000200002}$

SILVA, A.A., SILVA, P.R.F., SUHRE, E., ARGENTA, G., STRIEDER, M.L., RAMBO, L. 2007. Soil covering systems in the winter and its effects on maize grain yield grown in succession. Ciência Rural, v.37, n.4, p.928-935, 2007. http://dx.doi.org/10.1590/S010384782007000400002

SILVA, L.B.; NODARI, I.D.E.; SEABRA JÚNIOR, S.; DIAS, L.D.E.; NEVES, J.F. Production of lettuce under different cropping systems. Enciclopédia Biosfera, v.9, n.16, p.1742-1749, 2013.

SILVA, P.R.F.; ARGENTA, G.; SANGOI, L.; STRIEDER, M.L.; SILVA, A.A. Management strategies of winter cover crops to maize grown in succession in no-till system. Ciência Rural, v.36, n.3, p.1011-1020, 2006. http://dx.doi.org/10.1590/\$0103-

\section{$\underline{84782006000300049}$}

SOLINO, A.J.S.; FERREIRA, R.O.; FERREIRA, R.L.F.; NETO, S.E.A.; NEGREIRO, J.R.S. Organic crop of rocket in no-tillage on different types of mulching and doses of compost. Revista Caatinga, v.23, n.2, p.18-24, 2010.
SOUZA, M.C.M.; RESENDE, L.V.; MENEZES, D.; LOGES, V.; SOUTE, T. A.; SANTOS, V.F. Genetic variability for agronomic characteristics in lettuce progenies with heat tolerance. Horticultura Brasileira, v.26, n.3, p.354-358. 2008. http://dx.doi.org/10.1590/S0102$\underline{05362008000300012}$

SOUZA, M.; COMIN J.J.; LEGUIZAMÓN, E.S.; KURTZ, C.; BRUNETTO, G.; MÜLLER JÚNIOR, V.; VENTURA, B.; CAMARGO, A.P. Dry matter of cover crops, onion yield and soil chemical attributes in agroecological no-tillage system. Ciência Rural, v.43, n.1, p. 21-27, 2013. http://dx.doi.org/10.1590/S0103$\underline{84782012005000150}$

SUINAGA, F.A.; BOITEUX, L.S.; CABRAL, C.S.; RODRIGUES, C.S. Productive performance of crisp lettuce cultivars. Brasília: Embrapa Hortaliças, 2013. 15p. (Boletim de Pesquisa e Desenvolvimento, 89).

TEIXEIRA, C.M.; CARVALHO, G.J.; ANDRADE, M.J.B.; SILVA, C.A.; PEREIRA, J.M. Decomposition and nutrient release of pearl millet and pearl millet plus Crotalaria juncea straws on bean notill. Acta Scientiarum Agronomy, v.31, n.4, p.647653, 2009. http://dx.doi.org/10.4025/actasciagron.v31i4.135 $\underline{6}$

WUTKE, E.B.; CALEGARI, A.; WILDNER, L.P. Species of green manures and cover crops and recommendations for their use. In: LIMA FILHO, O.F.; AMBROSANO, E.J.; ROSSI, F.; CARLOS, J.A.D. (Ed.). Green fertilization and cover crops in Brazil: fundamentals and practice. Brasília: Embrapa, 2014. p. 59-168.

WUTKE, E.B.; AMBROSANO, E.J.; RAZERA, L.F.; MEDINA, P.F.; CARVALHO, L.H.; KIKUTI, H. Community fertilizer seed banks: technical information. Brasília: Ministry of Agriculture, Livestock and Supply, 2007.

YURI, J.E.; SOUZA, R.J.; FREITAS, S.A.C.; RODRIGUES JÚNIOR, J.C.; MOTA, J.H. Performance of crisphead lettuce cultivars in Boa Esperança, Brazil. Horticultura Brasileira, v.20, n.2, p.229-232, 2002. http://dx.doi.org/10.1590/S0102$\underline{05362002000200023}$ 
ZIECH, A.R.D.; CONCEIÇÃO, P. C.; LUCHESE, A.V.; PAULUS, D.; ZIECH, M. F. Cultivation of lettuce under different management of land cover and nutrient sources. Revista Brasileira de Engenharia Agrícola e Ambiental, v.18, n.9, p.948-954, 2014.

http://dx.doi.org/10.1590/1807-

1929/agriambi.v18n09p948-954

Recebido para publicação em 04/11/2017

Revisado em 02/09/2018

Aceito em 28/09/2018 